\title{
Managing University Through Waqf Assets: Evidence From Indonesia
}

\author{
G Gustina ${ }^{1}$, H Ihsan ${ }^{2}$ \\ Department of Business Administration, Padang State f Polytechnic, Limau Manis Campus, \\ Padang, Indonesia ${ }^{1}$ \\ Department of Accounting, Padang State f Polytechnic, Limau Manis Campus, Padang, \\ Indonesia $^{2}$ \\ \{umikhazid@gmail.com¹,ihsanm@gmail.com²
}

\begin{abstract}
Waqf and education is inseparable throughout history. It is undoubtedly true that waqf had been witnessed as one of the generators to the development of education in Islam. There are many universities around the world which were supported and funded by waqf assets. Among other things, Al Azhar University, which has been established from the 10th century, is financed through waqf assets. Interestingly, this university could provide free education for many students from all over the world. The success story of Al Azhar University in managing waqf assets supposedly could inspire other Muslim countries to implement the same way. In fact, Indonesia, as the largest Muslim population in the world, is highly potential to develop waqf assets in supporting the higher education. Nevertheless, the number waqf-based higher education institution in Indonesia is still very limited. On the other hand, the rising cost of higher education demands for an alternative source of funding. Waqf, indeed, could be the answer of this problem as it has been practiced for centuries. This study therefore aims to seek evidence regarding how waqf could support the higher education, in this case in Indonesian setting. A case study from a waqf-based university was conducted. The researchers selected UNISULLA, which is managed by Yayasan Badan Wakaf Sultan Agung (YBWSA) as a case. Through series of in-depth interviews, observations and document reviews, we found that the way YBWSA managed waqf assets throughout the time is very impressive. However, some important points should be addressed to maintain the sustainable nature of waqf in the future.
\end{abstract}

Keywords: waqf, higher education, case study.

\section{Introduction}

Throughout history, waqf is inseparable from the development of socio-economic aspects of Muslim society. Prophet Muhammad pbuh (peace be upon him) and his sahabah (companions) had initiated the foundation of waqf and later it had proven to be able to support the governments in providing many infrastructures. There were various physical facilities, ranging from the worship places to social needs, were supported by waqf assets. It is not surprising, therefore, waqf is regarded as part of Muslim's life. 
Historically speaking, there are many waqf assets were established to foster the development of education. For instance, Al Azhar University in Egypt, is one of the waqf assets established during the Fatimayad dynasty. This waqf asset is still very active in providing free education for many students from all over the world. Other examples of waqf based university among others are Al-Qurawiyin University in Morocco, Al-Muntasiriyyah University in Iraq and the University of Cordova in Spain. In fact, in Turkey alone, there were approximately 68 universities established and financed from waqf assets [1]. It indicated that education in Islam cannot be separated from the contribution of waqf. In other words, endowments have contributed significantly to higher education throughout history.

The model of waqf based higher education was later on replicated by many universities in the West. For instance, many well-known universities such as Oxford and Cambridge in England, or Harvard and Yale in the United States, were founded from endowment. Evidently, endowment system in the West is adapted from the waqf model. "... The Oxford and Cambride universities (the colleges) have adopted the idea of Islamic waqf to initially fund themselves" [1]. Indeed, the idea of waqf for higher education is not a new idea, even to the Western society.

Ironically, the idea of making waqf as one of the instruments to finance higher education tends to be neglected among the Muslim Community. In Indonesia, as the largest Muslim country in the world, it seems like there are only few universities that utilize the potential of waqf. The Islamic University of Indonesia, Sultan Agung University and Darus Salam Gontor University are among the few universities in Indonesia which are funded by waqf assets.

On the other hand, one of the problems faced by higher education in Indonesia recently is the budget issue. Although the national budget in 2016 for education is considered breaking the record, which is IDR419.2 trillion or $20 \%$ of total national expenditure, the allocation for the Ministry of Research and Higher Education is only 9.4\% [2]. Out of these, the portion for higher education would be lesser due to the fact that the higher education has merged under the ministry of research and technology recently. Meanwhile, another fact from the higher education which is under the Ministry of Religious Affairs is more apprehensive. Although the total budget allocated in 2016 to that ministry reaches IDR57.1 trillion, the remaining share for the development of higher education was only IDR600 billion [3].

The great potential offered by waqf instruments, as well as the fact that Indonesia has a huge number of potential donors (waqif) (Sudiaman, 2014), should be seen as the opportunity to develop waqf based university. However, the idea of supporting universities through waqf is less popular in Indonesia. This study, therefore aims to portray the current practice of higher education which is funded and supported by waqf assets.

This paper is organized as follows: The following section will briefly review the previous studies on waqf. It is then followed by the presentation of research method. The finding and discussion are presented respectively. Lastly, this paper concludes with some recommendations to improve waqf management.

\section{Related Works}

Literally, waqf means to stop, to hold, or stand still. Technically, waqf is defined as "...holding certain property and keeping it for the purpose of philanthropy and preventing it from usage other than the intended purpose" [4]. The scholars agreed that another term for waqf is sadaqah jariyah. It is mentioned in a hadith qudsi that one of the deeds that will continuously flow its reward to a Muslim, even though the person already died, is waqf. Although the term waqf itself cannot be found in the Qur'an, the practice of giving wealth for the benefit of the society has been taught by Prophet Muhammad pbuh and his companions. 
In accordance with its purpose that waqf is aimed for the public benefit, mutawalli/nazhir (manager) of waqf should prevent the use of waqf property from anything other than the purpose of its establishment [5]. Sadeq [6] adds that the ownership of waqf property should not be transferred; rather only the benefits of the waqf property may be taken. The intention of the establishment of waqf is the spiritual basis that is seeking the pleasure of Allah SWT. Moreover, although the common form of waqf property known by the Muslim community is immovable assets such land and buildings, according to Kahf [4], waqf can be in various forms such as; books, farming tools, farm animals, stocks and possessions, as well as cash.

Based on the purpose of its establishment, waqf can be categorized as waqf khairy (general waqf), waqf ahli (family waqf) and waqf mushtarak (mixed between khairy and wakaf ahli) [7]. Waqf khairy is a waqf devoted to the welfare of the public at large, while waqf hali is dedicated by the waqif (the waqf founder) for the children and their descendants. Wakaf mushtarak, on the other hand is a combination of wakaf khairi and wakaf ahli. It is usually formed in such a way that some part is addressed for the public benefit and the rest are intended for waqif's offspring.

Raissouni [5] classified waqf based on its functions that is waqf for worship, such as mosque; educational waqf, such as universities and schools, and waqf for social welfare, such as health facilities, clean water sources, and other public facilities. Apart from the abovementioned classification, the existence of waqf is expected to be a means to facilitate public to access facilities which are basic needs in nature, such as health, education, worship and others [6].

\subsection{Waqf in Indonesia}

Historically speaking, waqf in Indonesia is almost as old as Islam in the country. As mentioned by Gofar [8], waqf activities had been introduced in East Java, circa 1500s. Further, based on data from the Regional Office of the Department of Religious Affairs of East Java and Office of Religious Affairs, during the XVI century there was a waqf land about 20,615 M2. The number of waqf properties continued to grow throughout the time, both in the form of land and buildings. During the Dutch colonial period, the activities of waqf did not recede, as evidenced by the issuing of several regulations governing waqf property by the Dutch colonial government at that time [8], [9].

Gofar [8] identified that the traditional form of waqf in Indonesia was dominated by land and buildings. Those assets were mainly used to facilitate health service, schools, mosques, and orphanages. It is only in the last few years that cash waqf has raised its popularity among the waqf managers in Indonesia. Further, Gofar mentioned that there are two general patterns of waqf creation in Indonesia, namely individual and mutual cooperation. Individual endowments are those from generous Muslim individuals who want to donate their wealth for the benefit of the public, while mutual cooperation is usually done though crowd funding to obtain the intended waqf. Although waqf in Indonesia has long story, only few that are managed productively. The Modern Islamic Boarding Schools of Gontor [9] and Dompet Dhuafa [10] are among the well managed and productive waqf in Indonesia.

The biggest step made by the Indonesian government in revitalizing waqf was through the enactment of waqf law i.e. the Act No 412004 on Waqf. Indeed, this effort is not only considered as law reformation in waqf, but also a turning point towards a better management of waqf in the country. Indeed, this waqf Act has enforced some significant changes in waqf management in the last decade. Following the enactment of Waqf Act, a regulatory body on waqf that is the Indonesian Waqf Board (IWB) was formed to regulate all waqf institutions in 
Indonesia. This effort is expected to overcome many problems such as weak supervision and lack of accountability in waqf management which occurred over the years [10].

\subsection{Waqf and Higher Education}

As mentioned earlier, the development of educational institutions in Islamic history was inseparable from the role of waqf. Makdisi [11] notes that Al Azhar University in Egypt is the oldest educational institution established through waqf asset. Initiated by mosque and madrassas in the 10th century, Al Azhar was then developed into a university. The existence of this waqfbased university has inspired many countries subsequently. Countries like Morocco, Iraq, Spain, Turkey and Indonesia adopted the Al Azhar system in developing their higher education.

The most phenomenal development of waqf based universities can be found in Turkey [1]. There have been at least 68 waqf-based universities, and the number is potentially increasing every year in this country. According to Hashim [12], one of the advantages of universities funded by endowments is that they have the freedom to manage budgets and determine their curriculum. This may also inspire some universities in Malaysia to begin to look at potential sources of educational funding from waqf funds [1].

The success story of waqf in supporting higher education in Al Azhar had inspired the establishment of some universities in Indonesia. The Islamic University of Indonesia (Universitas Islam Indonesia) in Yogyakarta [13] and Sultan Agung Islamic University in Semarang [9] are among the universities initiated from waqf. In addition, University of Darussalam (Unida) Gontor was also originated from asset waqf which adopted the model of Al Azhar Univarsity, Egypt [13].

The fact that waqf has great potential in supporting higher education is undeniable. However, as to how the current practice of waqf based universities remained unexplored in the extent literatures. Some studies such as Bamualim [9], [13] only portrayed management aspects in general. Thus, the current study will explore in more details the existing practice of those waqf based universities.

\section{Method}

This research employed qualitative approach with case study as the research design. More specifically, this study falls into interpretive paradigm, which requires a good understanding and interpretation of the researchers on what the individuals in the organization are doing. Furthermore, there is no hypothetical-deductive model testing, since it is a character of quantitative research approach.

The researchers, therefore, selected Sultan Agung Waqf Foundation (Yayasan Badan Wakaf Sultan Agung or hereafter refers to as YBWSA) in Semarang as a case. The reason for choosing this case is because YBWSA is the mutawalli of one of the oldest universities in Indonesia, that is Sultan Agung Islamic University (UNISSULA), which is founded based on waqf. Basically, the justification for the selection of this case cannot be seen as sampling method. In qualitative research case selection is based more on theoretical aspects, not statistical sampling methods [14].

In conducting this research, the researchers used various methods, that is, through in-depth interviews, observation and document review. The use of various data sources is expected to help the researchers to understand more deeply the issue under study. Furthermore, data is analyzed through thematic analysis. 


\section{Result}

\subsection{A Brief History of YBWSA}

The history of YBWSA is almost as old as Republic of Indonesia, as an independent country. Right after the independence of Indonesia, some Muslim leaders in Semarang, Central Java, initiated an Islamic school to facilitate the education of Muslim children [15]. There were Kyai Tojib Thohari, Ustadz Abubakar Assegaf, R. Soerjadi, H. Chamiem and Ustadz Md. Tahir Nuri who took take part in initiating the idea of establishing a school to accommodate Muslim children as they rejected the colonial system and educational institution. The problem was that, there was no facility to run the school. Thus, some facilities such as building and school benches were borrowed from Haji Chaeron and Muhammadiyah organization. It was in 1947, those Muslim leaders later successfully established a permanent school, i.e. Al-Falah Islamic Elementary School (SRI Al Falah), located in Kampung Mustaram, Kauman Street Semarang.

To show their commitment in developing the education for Muslim society, the founders of SRI Al Falah later formed a waqf foundation. The aim of this waqf foundation was to empower any resources, particularly in the form of waqf, from the Muslim society to succeed the education. This waqf foundation was officially registered at the notary office at 31 July 1950 with a name Yayasan Badan Wakaf (YBW). In its organizational structure, YBW involved almost every element of Muslim community as the commissioners. In addition, the establishment of YBW was also supported by public figures, such as Ustadz Abdullah Hinduan, one of the alumni of Darul Ulum, Egypt who has successfully established and developed Waqf Board in Pekalongan.

Throughout the time, Yayasan Badan Wakaf managed to collect various waqf assets from the Muslim society. Those waqf assets were mainly used to support education. Later, in 1962 YBW had successfully established an Islamic university called Universitas Islam Sultan Agung. Following the establishment of the university, the YBW changed its name to Yayasan Badan Wakaf Sultan Agung (YBWSA), in 1967.

\subsection{Waqf Management in YBWSA}

Soon after the formation of YBW, it has received various waqf assets from the Muslim society. Some important events in the development of YBW as nazhir are as follows:

a) In its first meeting on 25 July 1950, YBW reported some waqf assets received from the donors. There was a house endowed by H. Chamiem worth IDR10,000, located on Jalan Kaligawe 15 Semarang. This asset was later registered at Notary Tan A Sioe No.2 / 1950. There were also a house worth IDR 5,000 and IDR 173.93 in cash donated through Kyai Abdullah.

b) In 1952, YBW received a piece of land as waqf from Sharifah Maryam bint Ahmad Al Juffrie, Ali ibn Ahmad Al Juffrie and Syarifah Fatimah bint Ahmad Al Juffrie. This land is located at Gang Suromenggalan No. 62 Semarang.

c) YBW received IDR 50,000 of Cash waqf from the Islamic Aid Fund in Jakarta through H. A. Ghaffar Ismail (as Secretary-General).

d) From 1950 to 1970 the YBW grew rapidly. In 1954, a two-storey building for a school was built on waqf land in Suromenggalan. In the same year, YBW started a four-year Secondary School to accommodate those students who graduated from SRI Al Falah and other Islamic schools. In the following years, YBW continued to expand its activity in establishing new Islamic schools, both at primary and secondary levels. 
e) There were two important moments of YBW between 1962 and 1967. First, as mentioned previously, YBW set up a university, i.e. UNISULLA in 1962 and the second one was the transformation of YBW into YBWSA. Hence, the activity of YBWSA encompasses almost every level of education, from primary school to higher education.

It is documented at the secretary office of YBWSA that there are currently approximately 18,794 square meters of waqf land under its administration. Meanwhile, throughout the time, YBWSA purchased about 368,506 square meters of land. Those lands were utilized to provide educational and health services.

\subsection{Managing the university}

Nowadays, YBWSA is well-known with its activity in managing a university through waqf assets. In fact, YBWSA is one among very few nazhirs in Indonesia which is concerned in developing higher education through waqf assets. Although actually waqf does not alienate from education in Indonesia, most of waqf based education are in the primary and secondary levels.

Currently, more than 15,000 students are enrolled in UNISULLA at various faculty and programs. Besides university, YBWSA also managed to establish a hospital to support those students who take medical sciences.

During its commencement, UNISULLA had only three faculties, i.e. Faculty of Religion, Faculty of economics and Faculty of natural sciences. Nowadays, there are 12 faculties established besides master and doctoral programs.

The University set its target in the future to be recognized internationally. Therefore, in order to achieve that mission, UNISULLA is very concerned in facilitating further education, trainings for the lectures and its staff. In addition, the students also showed remarkable achievements in many occasions and events, both in national and international levels.

\section{Analysis and Discussion}

There are some points should be addressed related to the discussion on waqf management in YBWSA. First, the development of waqf assets under YBWSA management is very impressive. The fact that they started the school without any properties and nowadays have managed many assets, has indicated that the commissioners of YBWSA worked very hard. In this sense, any effort made should be appreciated.

Second, the success story of YBWSA in managing waqf has proven that waqf is a powerful instrument to support the government. The case of YBWSA is the real example of how waqf could be utilized to provide facilities such as education and health services.

However, besides appreciation on the achievement of YBWSA, there is one important point of critic to ponder. During the interview, the nazhir at YBWSA mentioned that the only waqf assets under their administration are those used for schools, while the university's property is not part of waqf assets. As stated by the secretary general, "We are not sure, whether we can call this university [UNISULLA] is based on waqf or not. But for sure, our spirit is still based on waqf'.

This opinion actually could be a threat for waqf sustainability. If the universities' properties are not part of waqf, to whom those assets belong? Let say that in a very bad scenario YBWSA has to stop its activities. Will those assets be sold, transferred of bequeathed to other parties?

Perhaps some assets were purchased by YBWSA. But, one should remember that, without the first waqf donated by waqif, the existing assets would have never been existed. In addition, as asserted by Cizakca [16], any surplus from managing waqf assets should be added to the 
principal hence at the end the value of original waqf assets will increase. This is the way waqf assets were managed actually in the previous times.

Also, the nazhir should mind the idea of making waqf assets become productive, as taught in a hadith about waqf of Umar [17]. To maintain the sustainable benefit of waqf, nazhir is responsible to make waqf become productive. Thus, any income generated from waqf assets should be utilized to support the original waqf.

In the modern waqf management, some nazhir allocate the waqf surplus or profit to three main purposes. First, to be distributed to the beneficiaries, second to be allocated as reinvestment of waqf assets and third as remuneration of nazhir. In fact, the second point will subsequently increase the value of waqf assets. Any assets created or generated from waqf assets should be considered as part as waqf as well.

The waqf spirit of nazhir at YBWSA should be appreciated. However, the spirit only is not enough. It should be followed by the appropriate recording system of waqf assets. Nazhir at YBWSA should consider recognizing any addition of waqf assets, including the university as part of waqf.

\section{Conclusion}

It is undoubtedly true that waqf possess a huge potential in supporting higher education. Historically speaking, waqf had contributed significantly to the development of many universities around the word. This fact subsequently had inspired many countries to implement the same.

YBWSA is among the universities which adopted the success story of waqf based university of Al Azhar. In its initial years of establishment, the spirit of waqf was very strong where the founders of the university had eagerness to collect and manage waqf assets from various sources. It is worth to note that the efforts made by YBWSA in developing waqf assets is impressive.

Throughout the time, it seems like there is bias in nazhir's perception on waqf. Nazhir seems to be confused with any assets generated from waqf surplus. Nazhir assumes that the only waqf assets are those which were received as donation, while any assets generated later on is not part of waqf. In fact, both the surplus and principal of waqf assets should be recognized as waqf. Thus, it is important to keep the waqf spirit on the track so that could repositionate waqf to its initial intention. The proper recording system is therefore also important to maintain waqf assets.

\section{References}

[1] S. M. Mahamood and A. Ab Rahman, "Financing universities through waqf, pious endowment: is it possible?," Humanomics, vol. 31, no. 4, pp. 430-453, 2015.

[2] P. . Wicaksono, “Anggaran Pendidikan di APBN 2016 Cetak Sejarah,” Liputan 6, 2015. [Online]. Available: http://bisnis.liputan6.com/read/2356557/anggaran-pendidikan-diapbn-2016-cetak-sejarah. [Accessed: 09-Jun-2016].

[3] Nursyam, "Mencermati Anggaran Kementerian Agama," Nursyam UIN Surabaya, 2016. [Online]. Available: http://nursyam.uinsby.ac.id/?p=4351. [Accessed: 09-Jun2016].

[4] M. Kahf, "The role of waqf in improving the ummah welfare," in Singapore international waqf conference, 2007.

[5] A. Raissouni, Islamic "Waqf Endowment": Scope and implications. Rabat: Islamic Educational, Scientific, and Cultural Organisation, 2001.

[6] A. M. Sadeq, "Waqf, perpetual charity and poverty alleviation," Int. J. Soc. Econ., vol. 
29, no. 1/2, pp. 135-151, 2002.

[7] M. Ismail Abdel Mohsin, Cash waqf: A new financial product. New Jersey: Prentice Hall, 2009.

[8] A. Gofar, "Keberadaan undang-undang wakaf di dalam perspektif tata hukum nasional," Mimb. Huk., vol. 57, pp. 72-82, 2002.

[9] F. Prihatini, U. Hasanah, and Wirdyaningsih, Islamic law of zakat and waqf, theory and practice in Indonesia. Jakarta: Indonesian University Faculty of Law Publishing Agency, 2005.

[10] H. Ihsan, M. B. Sulaiman, N. Mohammad Alwi, and M. Adnan, "A study of accountability practice in Dompet Dhuafa waqf of Indonesia," J. King Abdulaziz Univ. Islam. Econ., vol. 30, no. 2, 2017.

[11] G. Makdisi, The Rise of Colleges. Institutions of Learning in Islam and the West. New York: Columbia University Press, 1981.

[12] N. Y. Ismon, R. Ramli, N. F. Dahalan, S. Romli, and R. Hashim, "Mekanisme wakaf sebagai instrumen pendidikan tinggi swasta: Prospek dan cabaran Kolej Universiti Islam Melaka sebagai IPTS," Wakaf Pendidik. Tinggi di Malaysia Satu Penantian, pp. 49-74, 2015.

[13] C. S. Bamualim and I. Abubakar, Revitalisasi Filantropi Islam: Studi Kasus Lembaga Zakat dan Wakaf di Indonesia. Jakarta: Pusat Bahasa dan Budaya, Universitas Islam Negeri Syarif Hidayatullah Jakarta dan Ford Foundation, 2005.

[14] P. Eriksson and A. Kovalainen, Qualitative methods in business research. Introducing qualitative methods. London: SAGE Publications Ltd, 2008.

[15] D. . Supadie, Wakaf menyejahterahkan Umat. Semarang: Unisula Press, 2015.

[16] M. Cizakca, A history of philanthropic foundations: The Islamic world from the seventh century to the present. Istanbul: Bogazici university press, 2000.

[17] R. Van Leeuwen, Waqfs and urban structures: The case of Ottoman Damascus. Amsterdam: Brill, 1999. 